ISSN : 2354-5852

e-ISSN : 2579-5783

\title{
Pengaruh Suplementasi Zinc terhadap Waktu Penyembuhan Luka Perineum pada Ibu Nifas
}

\author{
Jamhariyah $^{1}$ \\ ${ }^{1}$ Prodi Kebidanan Jember Jalan Srikoyo No. 106 Patrang Jember \\ *Email : jamhariyah64@gmail.com
}

\begin{abstract}
Zinc is a major mineral that the body needs during wound healing. Zinc supplementationhas been widely used as a major component for burns, diaperash due to lessions and other conditions. Perineal wound healing period in the normal puerperal women are 6-7 days. The purpose of this study was to determine the effect of Zinc supplementation on wound healing time of the perineum in the region Arjasa Public Health Center in 2015. The research method uses quasie experimental design with the design of the control group post test only. Its population is experiencing post partum mothers spontaneous rupture in the work area as much as 28 post partum mothers in Arjasa Public Health Center. Sampling was done by accidental sampling technique. The sample consisted of 26 post partum women who experienced spontaneous rupture. Of this sample there are 23 postpartum women were given supplements of Zinc and 23 postpartum women were not given zinc supplements. Results of data analysis using independent test two sample t-test obtained uncorrelated t count is greater thant t table (5.377>2.063), meaning that Ho is rejected. This shows there are influence of Zinc supplementation on perineal wound healing time in postpartum mother. Based on the results of this study, Zinc was instrumental in the proliferatife phase constriction of blood vessels and accelerate the formation of new networks of fibrin fibers that time faster wound healing.
\end{abstract}

Keywords : Zinc supplementation, perineal wound healing time

\section{Pendahuluan}

Zinc merupakan mineral utama tubuh yang merupakan komponen pembentukan lebih dari 300 enzim yang dibutuhkan saat penyembuhan luka, menjaga proses fertilitas orang dewasa dan proses pertumbuhan anak, sintesa protein, membantu reproduksi sel, menjaga penglihatan, merangsang imunitas dan mencegah radikal bebas. Zinc juga merupakan elemen utama esensial tubuh dalam menjaga kesehatan kulit dan mencegah terjadinya beberapa penyakit kulit tertentu. Suplemen Zinc sudah banyak dipakai sebagai komponen utama untuk luka bakar, bintik merah karena diaper dan kondisi lesi lainnya (Matsier, 2006).

Masa nifas merupakan masa pulih kembali, mulai dari persalinan selesai sampai alat-alat kandungan kembali seperti keadaan sebelum hamil lama masa nifas yaitu 6-8 minggu. Banyak perempuan mengalami robekan perineum pada saat melahirkan baik pada primipara maupun persalinan lanjut. Luka pada perineum terjadi bisa akibat tindakan episiotomi atau robek spontan. Luka episiotomi atau luka spontan yang telah dijahit umumnya dapat sembuh spontan, kecuali bila terdapat infeksi, ada yang sembuh normal dan ada yang mengalami keterlambatan dalam penyembuhannya luka episiotomi. Proses penyembuhan luka perineum yang normal adalah 6-7 hari post partum. Setelah ditelusuri lebih lanjut, mereka ternyata memiliki kebiasaan makanan yang kurang baik, seperti berpantang makan, makanan yang dimakan juga tertentu, khususnya lauk (makanan yang berprotein) (Danuatmaja, 2000).

Penyembuhan luka merupakan suatu proses perbaikan dari jejas di kulit atau jaringan lunak. Luka bisa disebabkan oleh suatu trauma atau sayatan bedah. Hal lain seperti luka karena tekanan (biasa disebut luka dekubitus atau luka ditempat tidur) merupakan tipe ulkus kulit yang cenderung menjadi luka. Kemampuan kesembuhan suatu luka tergantung dari lokasi dan dalamnya luka dan sangat dipengaruhi status kesehatan dan nutrisi pasien. Segera setelah luka, terjadi proses inflamasi dan sel dibawah dermis (Lapisan kulit dalam) akan memproduksi kolagen (jaringan ikat). Yang diikuti oleh regenerasi sel epitel (lapisan kulit luar). Kombinasi antara diet dan nutrisi akan memperbaiki kualitas penyembuhan luka melalui proses tersebut diatas atau dengan 
menghambat kerusakan karena inflamasi (Smeltzer, 2002).

Menurut penelitian Elok Widjianingsih pada tahun 2012 bahwa tingkat konsumsi makanan yang bergizi berpengaruh terhadap penyembuhan luka pada manusia. Zat gizi yang berpengaruh sendiri adalah mikronutrient atau zat gizi mikro Zinc. Zinc tersebut berpengaruh karena Zinc adalah mineral penting untuk membantu mempertahankan fungsi tubuh normal seperti penyembuhan luka, mineralisasi tulang, pertumbuhan jaringan, dan fungsi tiroid. Kekurangan zinc dapat menyebabkan anemia, cacat lahir, kemandulan, intoleransi glukosa dan proses penyembuhan luka yang lambat. Zinc dapat diperoleh secara alami dari makanan yang kita konsumsi maupun dari suplemen zinc.

Menurut World Health Organization (WHO) penurunan Angka Kematian Ibu (AKI) masih terlalu lambat untuk mencapai tujuan target millenium development goals (MDG's) dalam rangka mengurangi tiga per empat jumlah perempuan yang meninggal akibat hamil serta bersalin pada tahun 2015. Salah satu tujuan pembangunan MDG's adalah perbaikan kesehatan maternal. Kematian maternal dijadikan ukuran keberhasilan terhadap pencapaian targed MDG's, adalah penurunan $75 \%$ rasio kematian maternal (WHO, 2005).

Dinas Kesehatan Kabupaten Jember, sudah berusaha untuk menekan AKI dan AKB, sehingga pada tahun 2014 sudah menurun jauh dibandingkan tiga tahun terakhir, namun data itu ternyata masih cukup tinggi di Jawa Timur. Angka Kematian Ibu di Jember selama 2014 tercatat sebanyak 31 kasus dan menjadi peringkat kedua di Jatim dibawah Surabaya, sedangkan untuk Angka Kematian Bayi sebanyak 251 kasus menduduki peringkat ketiga dibawah Pasuruan dan Malang (Dinkes Kabupaten Jember, 2015).

Zinc mempunyai peranan khusus dalam metabolisme kulit dan jaringan ikat. Hal ini diketahui secara langsung semenjak zaman yunani kuno, ketika calamine lotion yaitu sejenis lotion kulit yang mengandung $\mathrm{ZnCO} 3$ pertama kali digunakan untuk kulit. Didalam dunia kedokteran, khususnya pada pasien pasca operasi diberikan zinc ( $\mathrm{ZnSO} 4)$ untuk mempercepat penutupan luka. Kemampuan zinc dalam mempercepat penutupan luka ini disebabkan karena zinc mempunyai peranan penting dalam sintesa protein dan proses replikasi (perbanyakan) sel-sel tubuh . Struktur kulit kita terdiri dari jaringan ikat yang tersusun oleh protein. Pada kondisi defisiensi zinc, maka proses sintesa protein dan replikasi dari sel-sel jaringan ikat bawah kulit akan menjadi terhambat. Sehingga proses penutupan luka akan terhambat pula (Wahyuningsih, 2009).

Berdasarkan teori yang mengungkapkan bahwa zinc mempunyai peranan khusus untuk mempercepat penyembuhan luka sehingga peneliti ingin meneliti pengaruh zinc terhadap penyembuhan luka tersebut. Kemudian dilakukan studi pendahuluan di Puskesmas Arjasa Kabupaten Jember karena di wilayah kerja Puskesmas Arjasa angka kejadian rupture perineum spontan masih tergolong tinggi yaitu dari 15 ibu primipara dan multipara terdapat 12 ibu yang mengalami rupture perineum spontan saat persalinan. Sehingga terdapat $80 \%$ ibu bersalin yang mengalami rupture perineum spontan.

Terjadinnya luka perinium dapat disebabkan oleh 2 faktor yaitu faktor indikasi ibu dan indikasi janin seperti bayi prematur, bayi besar, posisi abnormal, gawat janin (Willian R. Forte : 442). Banyak faktor yang mempengaruhi penyembuhan luka perineum di antaranya dipengaruhi oleh lingkungan, tradisi, pengetahuan, sosial ekonomi, penanganan petugas, kondisi ibu mobilisasi dini, vulva hygiene, luas luka, umur, vaskularisasi, stressor dan juga nutrisi. Kebijakan program kunjungan masa nifas oleh tenaga kesehatan terutama bidan yang dilakukan 4 kali, minimal ibu dan bayi baru lahir mencegah, mendeteksi dan menangani masalh - masalah yang terjadi. Jadwal kunjungan masa nifas adalah 6-8 jam pasca persalinan, 6 hari pasca persalinan, 2 minggu pasca persalinan dan 6 minggu pasca persalinan (Syarifudin, 2009).

Pemberian suplemen zinc pada ibu pasca persalinan baik primipara maupun multipara yang mengalami rupture perineum diharapkan dapat mempercepat proses penyembuhan luka perineum. Dari latar belakang tersebut peneliti ingin mengetahui adakah "Pengaruh suplementasi zinc terhadap waktu penyembuhan luka perineum di wilayah kerja Puskesmas Arjasa Kabupaten Jember.”

\section{Metode penelitian}


Penelitian ini menggunakan desain (rancangan) penelitian eksperimental, dengan jenis penelitian quasi experimental. Rancangan pada penelitian ini menggunakan rancangan Control group post-test only. Bentuk rancangan ini adalah sebagai berikut :

Control
Group
E
$\mathrm{K} \rightarrow \begin{gathered}\text { Eksperimen } \\ \text { Treatment }\end{gathered}$ $\begin{gathered}\mathrm{X} \\ -\end{gathered} \rightarrow \begin{aligned} & 0_{1} \\ & 0_{2}\end{aligned}$

Keterangan :

E : Kelompok Eksperimen

$\mathrm{K}$ : Kelompok Kontrol

$0_{1}$ : Pencapaian Kelompok Eksperimen

$\mathrm{O}_{2}$ : Pencapaian Kelompok Kontrol

$\mathrm{X}$ : perlakuan memberikan suplemen Zinc

- : perlakuan tidak diberikan suplemen Zinc

Pada kelompok eksperimen pemberian Zinc di konsumsi rutin setiap hari 1 tablet suplemen Zinc (20 mg) 1x/hari selama 7 hari.

Populasi dalam penelitian ini adalah semua Ibu bersalin yang mengalami Ruptur Perineum di wilayah kerja Puskesmas Arjasa periode 01 Juni - 30 Juni 2015 sebanyak 28 orang, dengan jumlah sampel sebesar 26 orang dengan teknik sampling accidental sampling.

Hasil perolehan data di analisa dengan teknik pengujian normalitas data dengan menggunakan Kolmogorov-Smirnov, uji ini digunakan untuk mengukur pengaruh antara dua variabel yang berskala rasio.

\section{Hasil dan pembahasan}

\subsection{Hasil Penelitian}

Hasil penelitian ini terdiri dari distribusi frekuensi usia ibu, paritas, rata-rata waktu penyembuhan luka, pengaruh suplementasi zinc terhadap waktu penyembuhan luka yang dapat dilihat pada tabel berikut.

Tabel 1. Distribusi frekuensi responden berdasarkan usia ibu nifas yang mengalami ruptur perineum spontan di wilayah kerja Puskesmas Arjasa Tahun 2015.

\begin{tabular}{ccc}
\hline Usia & Jumlah & $\begin{array}{c}\text { Persentase } \\
(\%)\end{array}$ \\
\hline
\end{tabular}

\begin{tabular}{ccc}
\hline$<20$ th & 8 & 31 \\
$20-35$ & 18 & 69 \\
\hline Jumlah & 26 & 100 \\
\hline
\end{tabular}

Berdasarkan tabel 1 usia ibu nifas $<20$ tahun sebanyak 8 orang yaitu $31 \%$, usia ibu nifas 20-35 tahun sebanyak 18 orang yaitu $69 \%$.

Tabel 2. Distribusi gambaran paritas ibu nifas yang mengalami ruptur perineum di wilayah kerja Puskesmas Arjasa tahun 2015

\begin{tabular}{ccc}
\hline Paritas & Jumlah & $\begin{array}{c}\text { Persentase } \\
(\boldsymbol{\%})\end{array}$ \\
\hline Primipara & 13 & 50 \\
Multipara & 9 & 35 \\
Nullipara & 4 & 15 \\
\hline Jumlah & 26 & 100 \\
\hline
\end{tabular}

Berdasarkan tabel 2. ibu primipara sebanyak 13 orang yaitu $50 \%$, ibu multipara sebanyak 2 orahg yaitu 35\% dan ibu nullipara sebanyak 4 orang yaitu $15 \%$.

Tabel 3. Distribusi frekuensi rata-rata waktu penyembuhan luka perineum yang diberikan suplemen Zinc di wilayah kerja puskesmas Arjasa tahun 2015.

\begin{tabular}{lcccc}
\hline \multicolumn{1}{c}{ Variabel } & $\begin{array}{c}\text { Mea } \\
\mathbf{n}\end{array}$ & SD & SE & $\mathbf{N}$ \\
\hline Waktu & 5.85 & 0.816 & 0.689 & 13 \\
penyembuhan & & & & \\
luka perineum & & & & \\
yang & & & & \\
diberikan & & & & \\
suplemen & & & & \\
Zinc & & & & \\
\hline
\end{tabular}

Berdasarkan tabel 3. rata-rata waktu penyembuhan luka perineum yang diberikan zinc adalah 5,85 hari dengan standar deviasi 0,816 . Jadi rata-rata waktu penyembuhan luka perineum yang diberikan zinc di wilayah kerja puskesmas Arjasa adalah 5,85 hari $=6$ hari.

Tabel 4. Distribusi frekuensi rata-rata waktu penyembuhan luka perineum yang tidak diberikan suplemen Zinc di wilayah kerja puskesmas Arjasa tahun 2015

\begin{tabular}{ccccc}
\hline Variabel & $\begin{array}{c}\text { Mea } \\
\text { n }\end{array}$ & SD & SE & N \\
\hline
\end{tabular}




\begin{tabular}{lllll}
\hline Waktu & 7.38 & 0.768 & 0.213 & 13 \\
penyembuhan luka & & & & \\
perineum yang & & & & \\
diberikan suplemen & & & & \\
Zinc & & & & \\
\hline
\end{tabular}

Berdasarkan tabel 4. rata-rata waktu penyembuhan luka perineum yang tidak diberikan zinc adalah 7,38 hari dengan standar deviasi 0,768. Jadi rata-rata waktu penyembuhan luka perineum yang tidak diberikan zinc di wilayah kerja puskesmas Arjasa adalah 7,38 hari $=7$ hari.

Tabel 5. Distribusi rata-rata pengaruh suplementasi zinc terhadap waktu penyembuhan luka perineum di wilayah kerja Puskesmas Arjasa Kabupaten Jember Tahun 2015

\begin{tabular}{llllr}
\hline \multicolumn{1}{c}{ Variabel } & Mean & SD & \multicolumn{1}{c}{ SE } & N \\
\hline Pengaruh & 1.538 & 0.94 & 0.28 & 26 \\
suplementasi & & 8 & 6 & \\
zinc & & & & \\
terhadap & & & & \\
waktu & & & & \\
penyembuha & & & & \\
n luka & & & & \\
perineum & & & & \\
\hline
\end{tabular}

Berdasarkan tabel 5. rata-rata pengaruh yang diberikan suplementasi zinc dan yang tidak diberikan terhadap waktu penyembuhan luka perineum adalah 1,538 hari dengan standar deviasi 0,948 . Jadi nilai mean untuk suplementasi zinc terhadap waktu penyembuhan luka perineum adalah: 1,538 hari $=1,5$ hari.

Tabel 6. Hasil uji normalitas data dengan Kolmogorov-Smirnov

\begin{tabular}{llr}
\hline & & \multicolumn{2}{l}{$\begin{array}{l}\text { Waktu } \\
\text { penyembuhan } \\
\text { luka }\end{array}$} \\
\hline Most Extreme & Absolute & 0.846 \\
Differences & Positive & 0.177
\end{tabular}

\begin{tabular}{lr} 
Negative & -0.846 \\
Kolmogorov- & 0.567 \\
Smirnov Z & \\
$\begin{array}{l}\text { Asymp. Sig. } \\
\text { (2-tailed) }\end{array}$ & 0.905 \\
\hline
\end{tabular}

Berdasarkan tabel 6. uji normalitas data dengan menggunakan Kolmogorov-Smirnov terlihat bahwa kolom signifikan (Asymp. Sig (2-tailed)) adalah 0,905 atau probabilitas lebih dari 0,05 maka Ho diterima yang berarti populasi berdistribusi normal.

Pengaruh Suplementasi Zinc terhadap waktu penyembuhan luka perineum yang sebelumnya telah diperiksa dan dianalisis menggunakan uji independent t-test 2 sampel tidak berkorelasi sebagai berikut : Harga $t$ hitung, dibandingkan dengan harga $t$ tabel. $\mathrm{dk}=n_{1}+n_{2}-2$. Dengan kesalahan $5 \%$, maka $\mathrm{t}$ tabelnya adalah $\mathrm{dk}=13+13-2=24$. sehingga di dapat $t$ tabel 2.063. Berdasarkan perhitungan tersebut, ternyata thitung lebih besar dari pada $\mathrm{t}$ tabel (5.377>2.063), dengan ( $p 0.000<\alpha$ $0.05)$, maka varians kedua group tidak sama. Dengan demikian Ho ditolak dan Ha diterima. Jadi kesimpulannya terdapat pengaruh suplementasi zinc terhadap waktu penyembuhan luka perineum.

\subsection{Pembahasan}

Berdasarkan hasil penelitian mengenai waktu penyembuhan luka perineum pada ibu nifas yang diberikan suplemen Zinc ternyata diperoleh hasil yaitu rata-rata waktu penyembuhan luka perineum pada ibu nifas yang diberikan zinc di wilayah kerja Puskesmas Arjasa dengan 13 responden adalah $5,85=6$ hari.

Zinc merupakan mineral utama tubuh yang merupakan komponen pembentukan lebih dari 300 enzim yang dibutuhkan saat penyembuhan luka. Beberapa peranan Zinc dalam proses penyembuhan luka adalah Zinc memegang peranan penting dalam proses pembentukan sel-sel darah merah dan sebagai sintesis dan degradasi karbohidrat, protein, lipida dan asam nukleat untuk memperbaiki jaringan kulit yang rusak (Matsier, 2006).

Fase-fase respon terhadap penyembuhan luka melputi fase inflamasi, fase proliferasi dan fase maturasi. Pada fase inflamasi terjadi respon vascular dan selular 
ketika jaringan terpotong atau mengalami cedera. Vasokonstriksi pembuluh darah terjadi dan bekuan fibrinoplatelet terbentuk dalam upaya untuk mengontrol pendarahan. Reaksi ini berlangsung dari 5 sampai 10 menit dan diikuti oleh vasodilatasi venula. Mikrosirkulasi kehilangan kemampuan vasokontriksinya karena norepinefrin dirusak oleh enzim intraseluler juga histamine dilepaskan yang meningkatkan permeabilitas kapiler (Morison, 2003).

Saat terjadinya luka pembuluh darah yang putus mengalami konstriksi dan retraksi disertai reaksi hemostasis karena agregasi trombosit yang bersama jala fibrin membekukan darah (Stevens, 1999). Albumin adalah alat transportasi Zinc dalam tubuh. Jadi, semakin banyak kandungan zinc dalam tubuh, maka jumlah albumin juga meningkat. Peningkatan jumlah albumin akan mempercepat produksi jala fibrin yang berfungsi membekukan darah. Zinc yang diserap di dalam tubuh akan bersama elemen darah seperti antibody, plasma protein, elektrolit, komplemen, dan air menembus spasium vascular yang menyebabkan edema, teraba hangat, kemerahan, dan nyeri. Hal tersebut merupakan tanda dari fase inflamasi. Berdasarkan teori tersebut dapat diketahui pada ibu nifas yang diberikan Zinc akan melewati fase inflamasi 2-3 hari yang termasuk waktu penyembuhan luka yang tergolong cepat.

Berdasarkan hasil penelitian mengenai waktu penyembuhan luka perineum yang tidak diberikan suplemen Zinc ternyata diperoleh hasil yaitu rata-rata waktu penyembuhan luka perineum yang tidak diberikan zinc di wilayah kerja Puskesmas Arjasa dengan 13 responden adalah 7,38 $=7$ hari.

Masa nifas merupakan masa pulih kembali, mulai dari persalinan selesai sampai alat - alat kandungan kembali seperti keadaan sebelum hamil yang berlangsung $6-8$ minggu. Ibu nifas yang mengalami robekan perineum umumnya dapat sembuh spontan, kecuali bila terdapat infeksi, ada yang sembuh normal dan ada yang mengalami kelambatan dalam penyembuhannya. Proses penyembuhan luka perineum yang normal adalah 6-7 hari post partum (Sulistyawati, 2009).

Fase penyembuhan luka yang pertama adalah fase inflamasi yang biasa disebut dengan fase perbaikan jaringan - jaringan yang rusak. Fse ini ditandai dengan eritema, hangat pada kulit, oedema, dan rasa sakit yang berlangsung sampai hari ke-3. Fase berikutnya adalah fase proliferasi disebut juga fase pertumbuhan jaringan baru dari serabut serabut kolagen yang menghasilkan prosuk akhir berupa fibrin yang merupakan hasil akhir dari aliran proses pembekuan. Fase ini berlangsung dari hari ke-3 sampai ke-21 (Stevens, 1999).

Faktor - faktor yang mempengaruhi proses penyembuhan luka perineum dibagi menjadi 2, yaitu faktor eksternal dan faktor internal. Faktor eksternal meliputi lingkungan, tradisi, pengetahuan, sosial ekonomi, penanganan petugas, kondisi kesehatan ibu dan status gizi. Sedangkan faktor internal meliputi usia, penanganan jaringan, hemorragi, hipovolemia, faktor lokal edema, defisit nutrisi, personal hygine, defisit oksigen dan overaktivitas (Smeltzer, 2002).

Berdasarkan teori di atas dapat diketahui bahwa waktu penyembuhan luka perineum yang normal adalah pada hari ke-6-7. Dengan melalui fase inflamasi sampai hari ke-3 dan fase proliferasi dimulai hari ke-3 sampai luka perineum tersebut bertaut sampai hari ke-7 post partum. Luka perineum yang belum bertaut pada hari ke-7 terjadi pada ibu yang kurang menjaga personal hygine, lingkungan ibu yang kurang mendukung dan tradisi.

Berdasarkan hasil uji independent t-test 2 sampel tidak berkorelasi di dapat nilai $t$ hitung lebih besar dari pada $\mathrm{t}$ tabel $(5.377>2.063)$ sehingga Ho ditolak. Jadi kesimpulannya terdapat pengaruh suplementasi zinc terhadap waktu penyembuhan luka perineum. rata-rata pengaruh yang diberikan suplementasi zinc dan yang tidak diberikan terhadap waktu penyembuhan luka perineum adalah 1,538 hari.

Suplementasi zinc adalah penambahan kandungan seng untuk konsumsi sehari - hari. Suplemen zinc yang diabsorpsi di dalam pencernaan membutuhkan alat angkut dan terjadi di bagian atas usus halus (duodenum). Zinc diangkut oleh albumin dan transferin masuk ke aliran darah dan dibawa ke hati. Zinc memiliki peranan penting dalam pembentukan sel darah merah, sebagai sintesis karbohidrat, protein, lipida dan asan nukleat untuk memperbaiki jaringan kulit yang rusak 
terutama pada proses penyembuhan luka (Matsier, 2006).

Setelah melewati persalinan, $80 \%$ dari ibu bersalin mengalami luka perineum (Dinkes Kabupaten Jember, 2012). Luka pada perineum terjadi bisa akibat tindakan episiotomi atau robek spontan. Luka episiotomi atau luka spontan yang telah dijahit umunya sembuh spontan, kecuali bila terdapat infeksi, ada yang sembuh normal dan ada yang mengalami kelambatan dalam penyembuhannya. Proses penyembuhan luka perineum yang normal adalah 6-7 hari post partum (Danuatmaja, 2000). Hasil penelitian Pengaruh Daun Sirih terhadap Penyembuhan Luka Perineum pada ibu nifas dan OR $=4,125$ (CI 95\% 1,387- 12,270) yang artinya pengunaan daun sirih memiliki risiko 4,125 kali lebih cepat kering dibandingkan yang tidak menggunakan daun siri (Kurniarum, 2014).

Berdasarkan teori di atas dapat diketahui bahwa luka perineum yang diberikan suplemen zinc akan sembuh lebih cepat dibandingkan dengan luka perineum yang tidak diberikan tambahan suplemen zinc. Hal ini dipengaruhi oleh pengaruh zinc yang berfungsi mempercepat vasokonstriksi pembuluh darah, pembentukan sel darah merah dan mempercepat produksi jala fibrin yang berfungsi membekukan darah, sehingga fase inflamasi akan berlangsung lebih pendek.

\section{Kesimpulan}

Rata-rata waktu penyembuhan luka perineum yang diberikan suplemen Zinc adalah 5,85 hari. Rata-rata waktu penyembuhan luka perineum yang tidak diberikan suplemen Zinc adalah 7,38 hari. Terdapat pengaruh suplementasi Zinc terhadap waktu penyembuhan luka perineum pada ibu nifas dengan rata-rata selisih waktu 1,5 hari. Hal ini disebabkan karena tablet zinc dengan dosis $20 \mathrm{mg} /$ hari mempunyai peranan penting untuk membantu proses penyembuhan luka perineum. Zinc diangkut oleh albumin. Albumin sangat dibutuhkan untuk proses penyembuhan luka. Jadi, jika di dalam tubuh banyak kandungan Zinc maka akan semakin banyak albumin yang dihasilkan, sehingga luka akan lebih cepat sembuh.

Petugas kesehatan baik di Puskesmas maupun kader kesehatan di Posyandu diharapkan ikut serta memberikan penyuluhan kesehatan tentang perawatan luka perineum pada ibu nifas dan perawatan untuk mencegah infeksi, serta diharapkan ibu dan keluarga lebih mengerti dan termotivasi untuk melakukan perawatan luka perineum sesuai prosedur, sehingga dapat mengurangi resiko terjadinya infeksi. Diharapkan kepada ibu nifas bahwa selain dengan perawatan luka perineum dari luar, ada juga teknik perawatan luka per oral yaitu dengan pemberian suplemen Zinc sesuai kebutuhan dengan tetap memperhatikan hygiene pada luka perineum.

\section{Daftar pustaka}

Farrer, Helen. 2001. Perawatan Maternitas. Forte, R. William.2010. Ilmu kebidanan : Patologi \& fisiologi persalinan. Yogyakarta : ANDI YEM

Matsier Al Sunita. 2006. Prinsip dasar ilmu gizi. PT. Gramedia Pusaka Utama. Jakarta

Morison, Moya J. 2003. Manajemen Luka. Jakarta : EGC

Prawirohardjo, Sarwono. 2002. Ilmu Kebidanan. Jakarta : YBSP

Price \& Wilson. 2001. Patofisiologi. Jakarta : EGC

Smeltzer S. C. 2002. Buku ajar keperawatan medikal bedah. EGC. Jakarta

Stevens, P.J.M.1999. Ilmu Keperawatan Jilid 2. Jakarta : EGC

Stillman, Richard M. 2010. Wound care.www.webmd.com.13 Maret 2015

Sulistyawati, Ari. 2009. Buku Ajar Asuhan Kebidanan pada Ibu Nifas. Yogyakarta : ANDI

WHO. $2005 . \quad$ Maternalmortality. http://www.who.int/reproductivehealt h/publications/maternal_mortality_20 05/index.html. diakses Sabtu, 30 Januari 2015 